\title{
Spatial-Temporal Analysis of LU/LC Classification in Nirmal Mandal, Adilabad, Telangana State, India, by Using Remote Sensing and GIS
}

\author{
Dr T. Madhu', D. Naresh Kumar'1, D. Niteesh Reddy², P. V. E. Ravi Teja², L. Narayana², V. Vishal ${ }^{2}$, \\ B. Subash ${ }^{2}$, A. Maniratnam², Y. Vasavi ${ }^{2}$, V. Shakeena ${ }^{2}$
}

${ }^{1}$ Sri Venkateswara University, Tirupati, India

${ }^{2}$ St. Martin's Engineering College, Civil Engineering Department, Secunderabad, India

Email: naresh.geology@gmail.com

How to cite this paper: Madhu, D.T., Kumar, D.N., Reddy, D.N., Teja, P.V.E.R., Narayana, L., Vishal, V., Subash, B., Maniratnam, A., Vasavi, Y. and Shakeena, V. (2017) Spatial-Temporal Analysis of LU/LC Classification in Nirmal Mandal, Adilabad, Telangana State, India, by Using Remote Sensing and GIS. International Journal of Geosciences, 8, 1315-1331. https://doi.org/10.4236/ijg.2017.811076

Received: August 14, 2017

Accepted: November 12, 2017

Published: November 15, 2017

Copyright $\odot 2017$ by authors and Scientific Research Publishing Inc. This work is licensed under the Creative Commons Attribution International License (CC BY 4.0).

http://creativecommons.org/licenses/by/4.0/

\begin{abstract}
In this project, we studied land use and land cover classification of Nirmal Mandal, Adilabad district, Telenagna state by using Geographical Information system and Remote sensing techniques. LISS-IV satellite image resolution $5 \mathrm{~m}$ $\times 5 \mathrm{~m}$ provides quality information for identification of Land use/Land cover characteristics. The image accuracy shows $45.70 \%$ of Agricultural land, $9.10 \%$ Built-up land, Forest area is $7.90 \%$, Barren land have $7.60 \%$ and Uncultivated land occupied $29.70 \%$. National land use and land cover mapping report based on 5 divisions classified in the study area. The area land use and land cover classification provide reliable data to understand land, water, soil, forests, urban sprawl. This socio economic survey significantly shows the changes that so far have taken place. This will help the people/farmers for the future land use and land cover change detection. Regular monitoring of agriculture, forest and greening efforts for plantation at suitable area, schemes and limitations. Free ware browsing of land cover gives sufficient development to plenty resource.
\end{abstract}

\section{Keywords}

Nirmal Mandal, GIS, LU/LC Classification

\section{Introduction}

The changes on the Earth's surface can be observed from the two aspects. Firstly, if time scale is observed when the changes have taken place, the changes can be 
different. In this sense, the changes can be related to the variations of the natural disasters (e.g. floods, fires) or to the geological events (e.g. the creation of the continents), and in that sense, time can be seen as a short period (fires that last for several hours or several days) or it can be one long continual period (the creation of the continents-several hundred years). Secondly, the changes can be observed from the spatial aspect, i.e. the occurrence of the different changes as a consequence of a local event (a road or a bridge construction) or the changes on the global level (the increase of the sea temperature or the melting of ice areas) [1]. When the changes on the Earth's surface are observed only from these two aspects, the time and spatial, it is clear that the nature of the change occurrence is complex and it is very difficult to perceive and make a conclusion or make a decision, because of the mutual relation and dependence of these two factors. So, the change detection represents one very serious and challenging task. Determination of the changes which occur on the Earth in the context of the digital image processing require different procedures and techniques, some of which are standardized, while many other depend on the applications in which the image processing is being done. In order to compare one image to another it is necessary to compare the pixel of one image to the pixel of another.

What is necessary to know before the detection process itself is the value of the change phenomenon which is very important, i.e. it is necessary to conduct the filtration of the certain changes. This can vary from one user to another, and from the purpose of change detection. There are several methods for mapping land cover changes using remotely sensed data: conventional maximum likelihood classification, post-classification, image differenciation, and principal components change-detection techniques, vegetative index differencing, post-classification change differencing, multi-date unsupervised classification.

Many diverse types of spatial data are needed to study and understand dynamic process, as well as to develop the environmental simulation models that are needed for scientific assessment of environmental problems and effects of human interactions on environmental quality. Multi-disciplinary data sets of land surface/subsurface characteristics are essential inputs to such studies. The multi-objective models require data on the multi-temporal behavior of land surface properties, as well as the parameterization of spatially heterogeneous and complex, landscape characteristics. Such spatial data sets are needed for different decision support systems. And increasingly use an integrated/coupled systems approach to modeling process across multiple time, space scales and helps in identification of suitable sites for different applications. Remote sensing technology is essential to the development of many spatial data sets for the study of environmental process. GIS complements remote sensing by providing the framework for integrated spatial analysis of diverse data structures in order to help understand and parameterize land surface processes. GIS also has a role in developing and tailoring integrated spatial data sets, including remote-sensing-derived thematic layers, for input to models. This study introduces spatial data issues 
involving data collection strategies, the use of cartographic and remote sensing products as sources of digital data, digital characteristics of spatial databases, and archival sources.

Land cover can be determined by analyzing satellite and aerial imagery. Land use cannot be determined from satellite imagery. Land cover maps provide information to help managers best understand the current landscape. To see change over time, land cover maps for several different years are needed. With this information, managers can evaluate past management decisions as well as gain insight into the possible effects of their current decisions before they are implemented. Coastal managers use land cover data and maps to better understand the impacts of natural phenomena and human use of the landscape. Maps can help managers assess urban growth, model water quality issues, predict and assess impacts from floods and storm surges, track wetland losses and potential impacts from sea level rise, prioritize areas for conservation efforts, and compare land cover changes with effects in the environment or to connections in socioeconomic changes such as increasing population [2] [3] [4].

Remote sensing has become an important tool applicable to developing and understanding the global, physical processes affecting the earth. Recent development in the use of satellite data is to take advantage of increasing amounts of geographical data available in conjunction with GIS to assist in interpretation. GIS is an integrated system of computer hardware and software capable of capturing, storing, retrieving, manipulating, analyzing, and displaying geographically referenced (spatial) information for the purpose of aiding development-oriented management and decision-making processes [5] [6] [7]. Remote sensing and GIS have covered wide range of applications in the fields of agriculture, environments, and integrated eco-environment assessment. Several researchers have focused on LU/LC studies because of their adverse effects on ecology of the area and vegetation $[8]$.

Change detection in watersheds helped in enhancing the capacity of local governments to implement sound environmental management [9]. This involved development of spatial and temporal database and analysis techniques. Efficiency of the techniques depends on several factors such as classification schemes, spatial and spectral resolution of remote sensing data, ground reference data and also an effective implementation of the result. Coastal environment changes were analyzed through qualitative evaluation techniques. The techniques included change map derived from vegetation index differencing, Image ratioing, image differencing and image regression. The basic principle of all change detection techniques was that the digital number of one date is different from the digital number of another date [10] [11]. Remotely sensed change detection based on artificial neural networks presents a new technique for multispectral image classification using training algorithm. The trained neural network detected changes on a pixel-by-pixel basis in real time applications. The trained four-layered neural network provided complete categorical information about the nature of changes and detected complete land-cover 
change "from-to" information, which is desirable in most change detection applications. Post classification change detection techniques with the comparison of land-cover classifications of different dates have limitations, as it does not allow the detection of subtle changes within land-cover categories.

Land use and land cover change has become a central component in current strategies for managing natural resources and monitoring environmental changes. The advancement in the concept of vegetation mapping has greatly increased research on land use land cover change thus providing an accurate evaluation of the spread and health of the world's forest, grassland, and agricultural resources has become an important priority [12] [13]. Viewing the Earth from space is now crucial to the understanding of the influence of man's activities on his natural resource base over time. In situations of rapid and often unrecorded land use change, observations of the earth from space provide objective information of human utilization of the landscape [14] [15]. Over the past years, data from Earth sensing satellites has become vital in mapping the Earth's features and infrastructures, managing natural resources and studying environmental change.

\section{Study Area}

The Normal Mandal located in Adilabad district of Telangana state and its lies on North Latitudes $18^{\circ} 56^{\prime}$ to $19^{\circ} 12^{\prime} 30^{\prime \prime}$ and East Longitudes $78^{\circ} 15^{\prime}$ to $78^{\circ} 25^{\prime}$, total area is covered about 218 sq.km with an elevation of $340 \mathrm{~m}$, surrounded by 14 lakes which make the place special (Figure 1). It is political headquarters of the district with a history of 400 years. Nirmal is the industrial epicenter of the district. It has a major transportation hub, with easy access to all major forms of transportation.

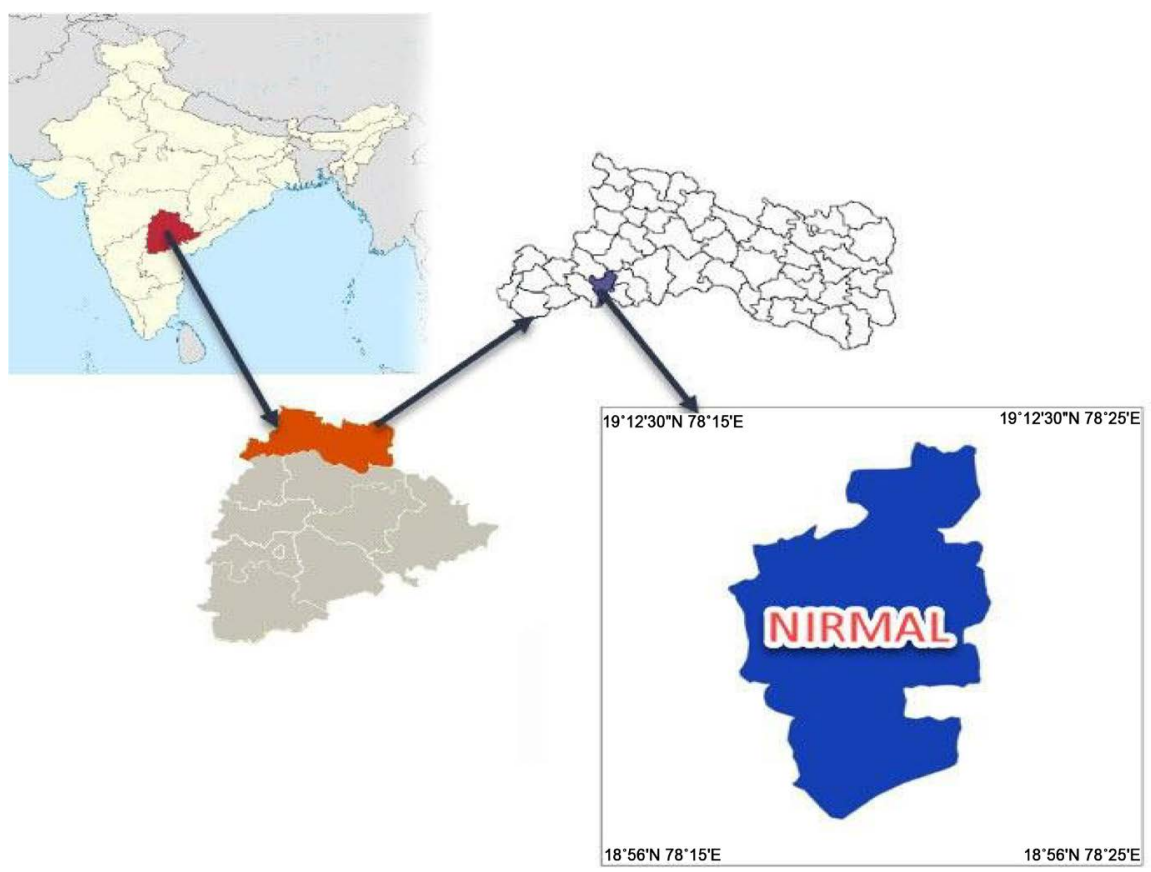

Figure 1. The study area of the Nirmal Mandal, Adilabad, Telangana, India. 
The climate of the town is characterized by the hot summer and is generally dry except during the southwest monsoon. The year may be divided into four seasons. The cold season from December to February is followed by the summer season from March to May. The period from June to September constitute the southwest monsoon season, while October and November from the post monsoon season. The relative humidity is high during the southwest monsoon season [16] [17]. The air is generally dry during the rest of the year, the district part of the year being the summer season when the humidity in the afternoon is $25 \%$. The rainfall in the Mandal, in general increases from the southwest towards the northeast. About $85 \%$ of annual rainfall is received during the southwest monsoon season. The peak rainy month is July. The variation in the Annual rainfall of a year is not very large. Annual rainfall of the district is $1044.5 \mathrm{~mm}$. The cold weather commences towards the end of November when the temperature begins to fall rapidly [18] [19].

December is generally the coldest month, with the daily maximum temperature of about $29^{\circ} \mathrm{C}$ and the minimum of $3^{\circ} \mathrm{C}$ In summer, from mid April the temperature begins to rise rapidly. May is generally the hottest month, with daily maximum temperature around $50^{\circ} \mathrm{C}$. Winds are light to moderate with some strengthening in the period from May to August. During the post monsoon and cold season, winds blow mostly from the east or northeast. By March, south westerlies start blowing and continue the rest of summer. The southwest monsoon season winds are mostly from directions between southwest and northwest.

\section{Socio Economic}

Nirmal Mandal, with population of about 1.4 lakh is Adilabad district's the $3^{\text {rd }}$ most populous sub district, located in Adilabad district of the state Telangana in India. There are 33 villages in the sub district, among them Soan is the most populous village with population of 4814 and Nagnaipet is the least populous village with population of 3 . Yellareddipet is the biggest village in the sub district with an area of $14 \mathrm{~km}^{2}$ and Old Pochampad is the smallest with $10 \mathrm{~km}^{2}$. There is only one city in the sub district that comes under the sub district administration which is Nirmal Municipality. The majority of the population, nearly $63 \%$ (about 88 thousand) live in Nirmal Sub District urban part and 37\% (about 51 thousand) population live in the Nirmal Sub District rural part.

Population of the sub district has increased by $15 \%$ in last 10 years. In 2001 census total population here were about 1.2 lakh. Female population growth rate of the sub district is $16.5 \%$ which is $3 \%$ higher than male population growth rate of $13.5 \%$. General caste population has increased by $14.7 \%$; Schedule caste population has increased by $15.4 \%$; Schedule Tribe population has increased by $22.7 \%$ and child population has decreased by $5.7 \%$ in the sub district since last census.

\section{Rainfall}

Rainfall is important for the development of the country as it helps for the 
growth of the crops. So the changes in the rainfall is been represented by the graph below.

From the above data of the graph we can say that 10 years once there is a heavy rainfall and also for every 3 years interval there is same amount rainfall for the consecutive years by this we can predict the rainfall of the future years. We can also observe there are 4 peaks in the graph which represents the high rainfall (Figure 2).

\section{Software Used: QGIS}

Geographic Information Systems (GIS) is a tool used to display, create, and analyze spatial information to help solve real world problems. It combines the graphics that make up a map with data tables of associated attributes. GIS Applications allow you to create many different types of maps from the same data. GIS is a great visualisation tool that can show you things about your data and how they are related in space (e.g. those disease outbreaks we saw earlier [20] [21]. Paper maps need to be filed and are time consuming to view. The GIS can hold a very large amount of map data and make it quick and easy to find a place you are interested in. QGIS is a GIS platform that is available as a free web-download. Features of QGIS include; importing data from multiple sources, Digitizing, Editing, on the fly reprojection, Geo-processing, Database connectivity; and Raster processing, Professional and easy print layout function.

\section{Methodology}

Toposheet no. E44A8 is been collected from the survey of India Hyderabad and these are been scanned by the drum scanners and converted into the.jpg file. The toposheet is been used as a base maps to create thematic maps by using QGIS (Quantum GIS). The following is the process for generating thematic maps which are useful for the change detection of land use land cover of an area, using SOI (Survey of India) toposheet as a base reference.

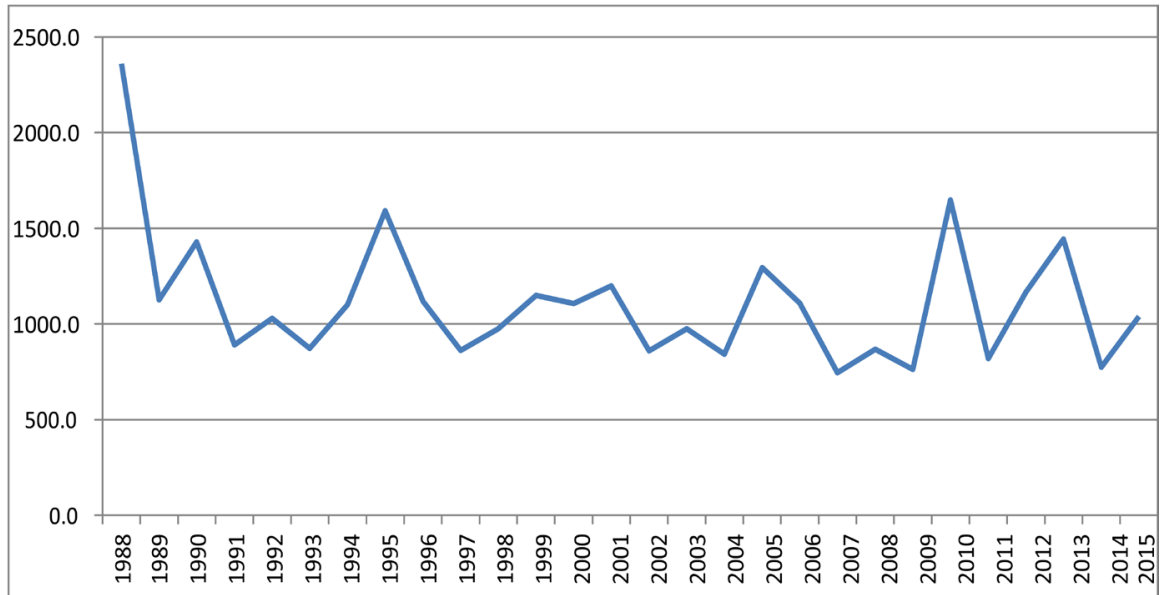

Figure 2. Graphical representation of rainfall in Nirmal Mandal, Adilabad, Telangana state. 
Geo-referencing of a toposheet has been done in QGIS (Quantum GIS) before generating the base map to obtain the geographical coordinates to the map. Add the geo-referenced toposheet as the raster layer in the Quantum GIS. Add the shape file layer to extract the study area from the toposheet. After extracting the study area from the toposheet different type of classes like roads, waste land, built-up land, agriculture land, drains, ponds, etc are drawn using line, point, polygon shape file layers in the Quantum GIS (Figure 3). The study area is classified with five classes namely Water bodies, Built up, Agriculture, Forest and Barren land [22] [23].

\section{Results}

\subsection{Classification of Land Use/Land Cover}

\section{Built-up land:}

Population grow thing increases year by year for that reason the significant pressure dominant on construction of the buildings of land cover area, which will effect on the environmental change in a large region. Frequent monitoring of the build-up land area provide good information of sustainable development of an area, Monitoring of changes in this category the best solution is to determine particular study area of the previous information with periodic intervals. Human exertion was affected by the urban land conspicuous landscape on the earth (Plate 1(a) and Plate 1(b)). Changes of build-up land due to the urban growth mainly the residential building construction shifting and development of

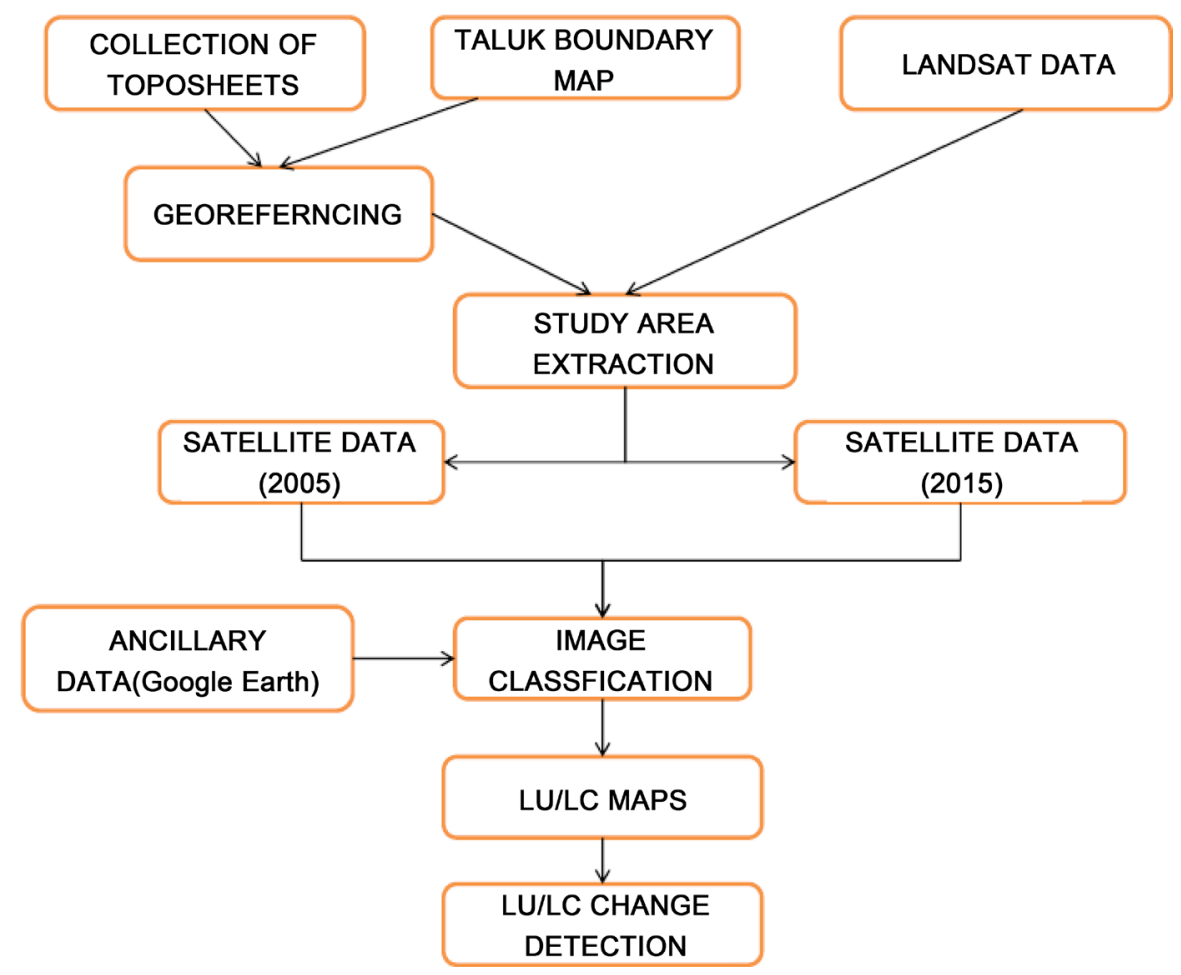

Figure 3. Preparation of LU/LC thematic map by geographical and remote sensing procedure. 


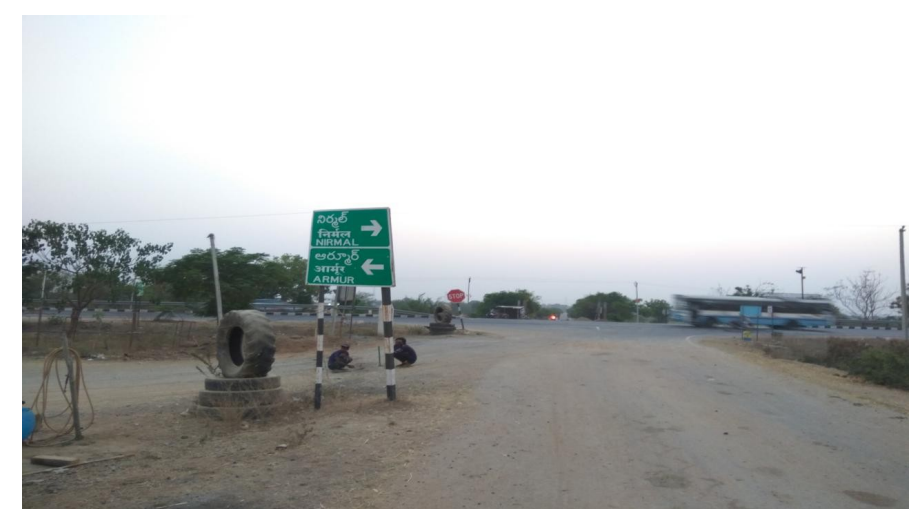

(a)

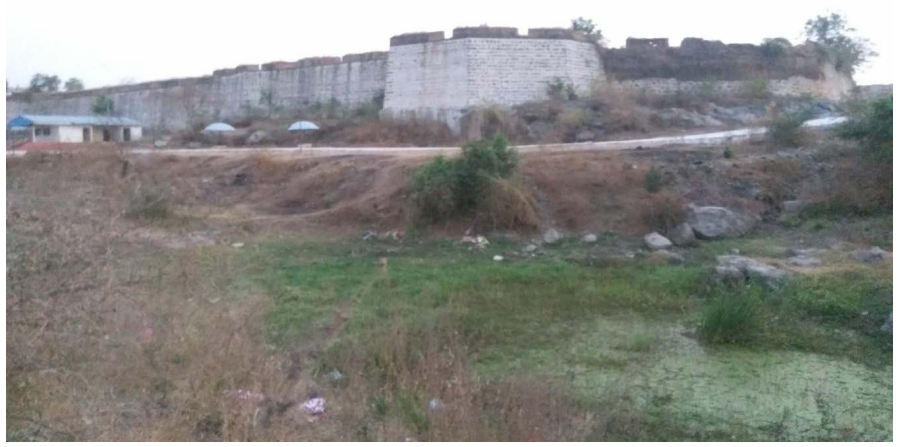

(b)

Plate 1. (a) Sangampet Road, Nirmal Mandal, Adilabad district, Telangana; (b) Shamgarh Fort in Nirmal Mandal, Adilabad district, Telangana.

commercial area in rural region, continuous migrating of regional economy, rapid increase of the urban population and unexpected growth in the urban area that results on the change of landscape area [24]. The common changes are in urban area includes construction, Real estate of corporate sector, education institutes and goes down or increases. Impacts of urbanization are concentrated Cultivation land, Waste land, Forest land, Water bodies and other geographical areas. The recent technology provides full accurate data of change determination that will help to understanding the damage of ecosystem and environment. Remote sensing and GIS is good software to planning and operation of decision that results in the effect of urbanization [25] [26] (Plate 2(a)).The attribute data of land use/land cover from the study area barren land contains 9.1\% (Figure 4).

\subsection{Agriculture Land}

Indian economy mainly depends on the Agriculture land area it is an essential source to produce of food for human survival. The satellite data is best technology to take decision and understand the crop occupation area, grow thing, consuming of taxes on the crop land, Crop production and food securities etc., Land use and land cover data provides full information of crop land details with sea- 


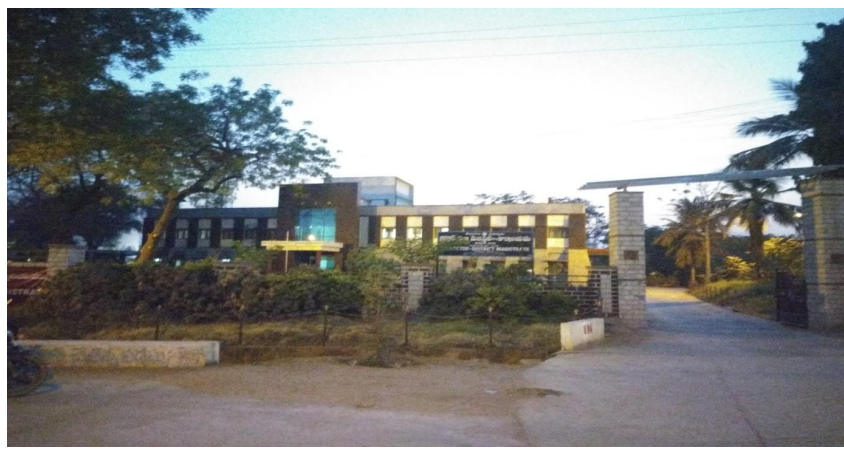

(a)

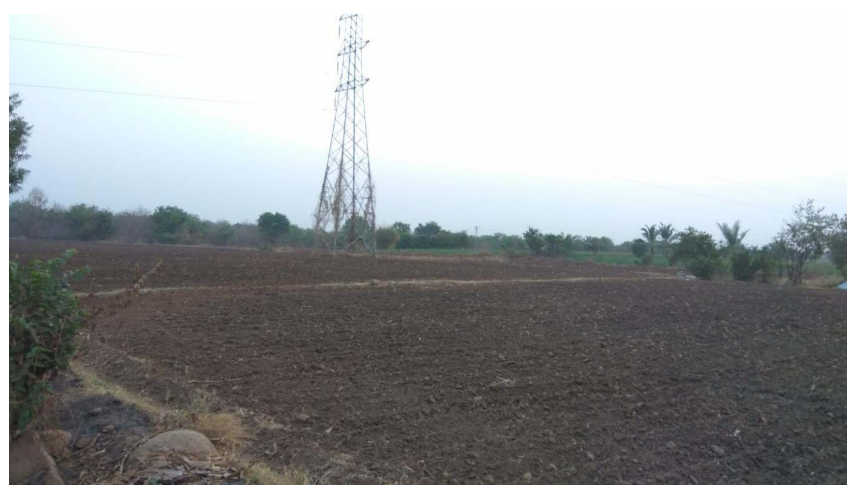

(b)

Plate 2. (a) New Collectorate Nirmal Mandal, Adilabad district, Telangana; (b) Cultivation land, Nirmal Mandal, Adilabad district, Telangana State.

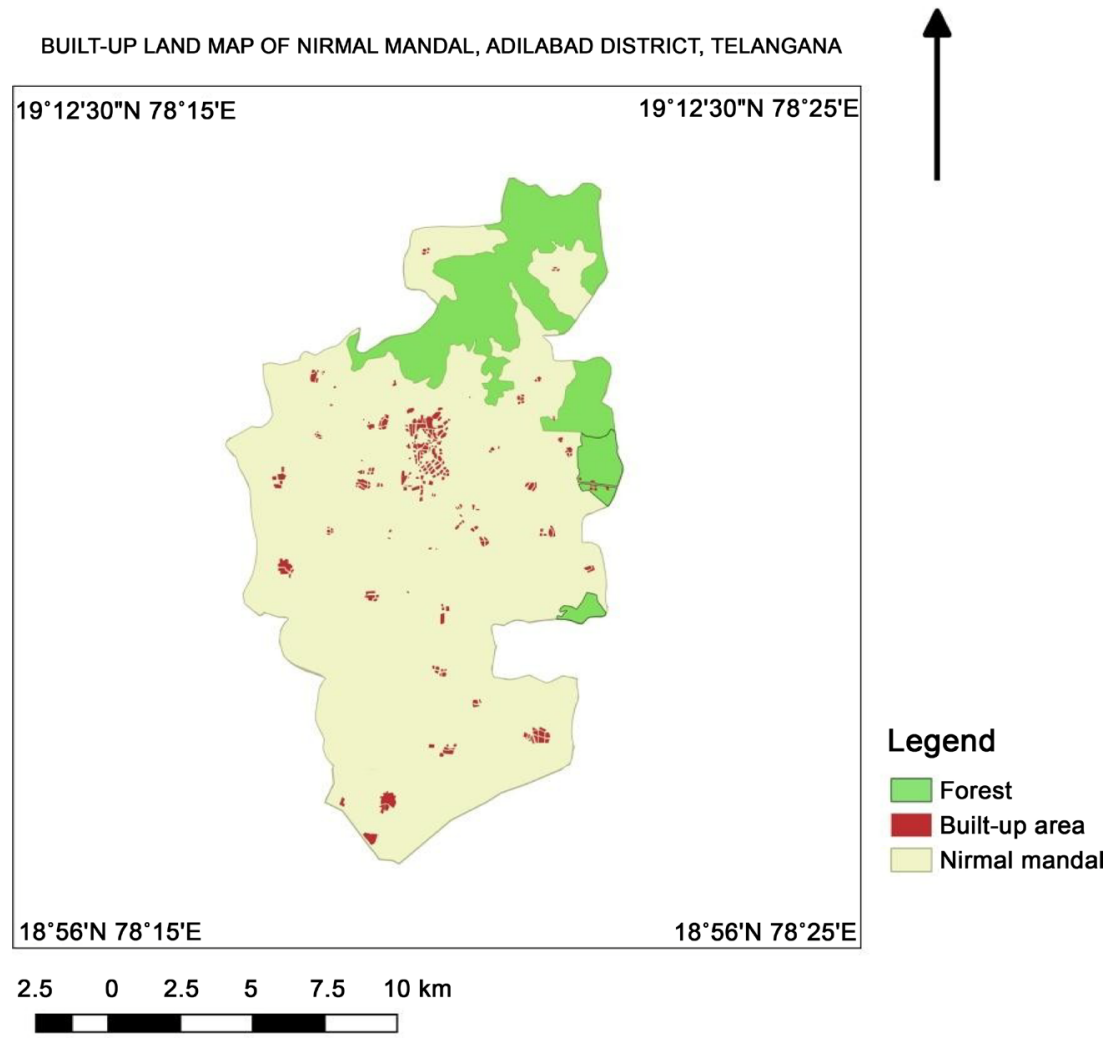

Figure 4. Build-up land of Nirmal Mandal, Adilabad, Telangana, India. 
AGRICULTURE LAND MAP OF NIRMAL MANDAL, ADILABAD DISTRICT, TELANGANA

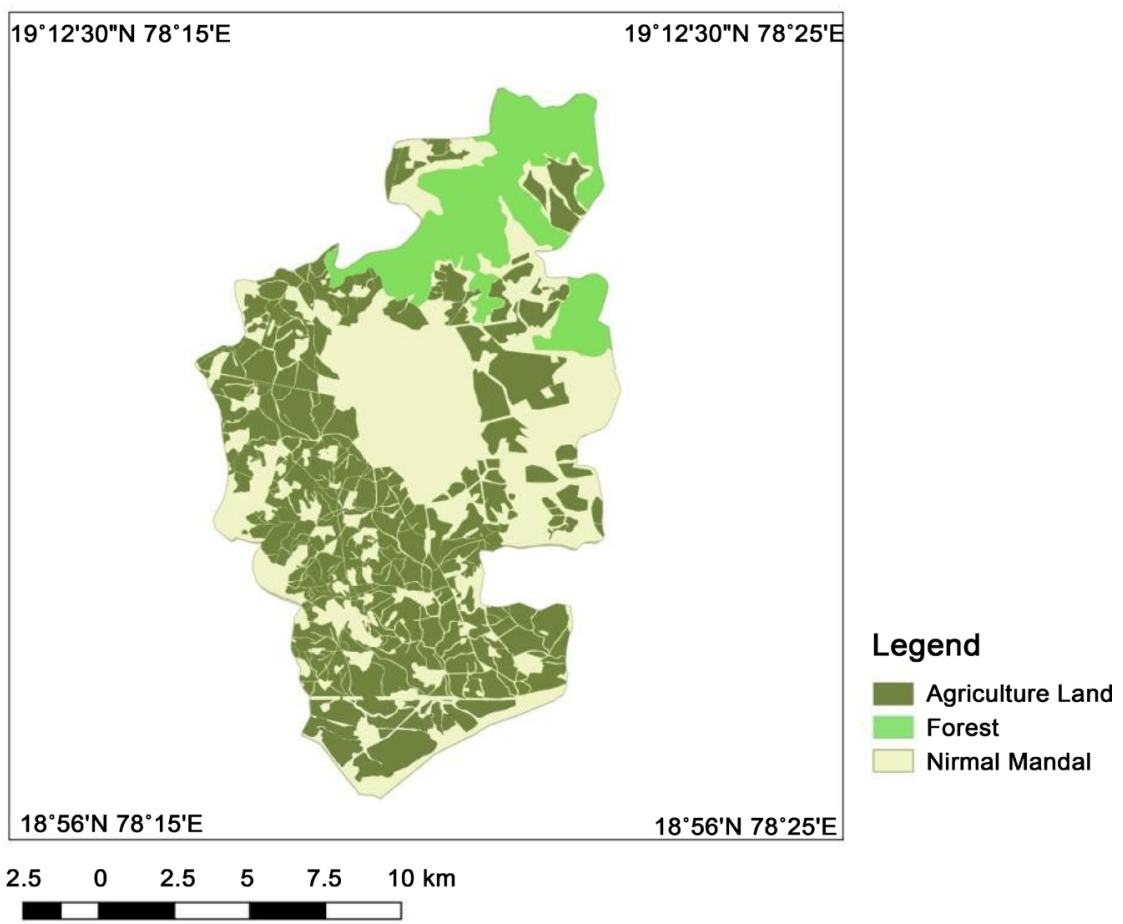

Figure 5. Agriculture land of Nirmal Mandal, Adilabad, Telangana, India.

sonal wise. Comparison of multispectral and hyper-spectral image processing results of results of seasonal crop identification and classification (Figure 5). The advanced survey of vegetation mapping has influenced to determine the accurate results on the agriculture, grasslands as they as precedents in study area. Population grow thing, reducing of forest land and unexpected development impact on the reduction of agriculture land. [27] [28] (Plate 2(b)) Agriculture land has $46 \%$ in the total geographical area (Figure 5 ).

\subsection{Forest}

In an Ecosystem Forest plays a major role and to Forest to conserve environmental arrangement. The different Environmental cycles are all depends on the forest region only, it provides not only food, fiber, timber and also it consumes carbon dioxide and releases organic living source of oxygen gas. It helps in the improvement of the welfare of human society as well as supportable livelihood there are many Ecosystem services inbuilt in biodiversity. Consumption of forest resources in a non-sustainable manner leads to the environmental degradation [29] [30]. Understanding of forest land changes to provide the quality of life and economy of the country. The attribute data of land use/land cover from the study area has forest land 7.9\%. Forest land is protected well and there is no effect of urbanization on the forest land (Figure 6).

\subsection{Water Bodies}

Water is essential resources for leaving of human life. The main sources of water 
FOREST MAP OF NIRMAL MANDAL, ADILABAD DISTRICT, TELANGANA

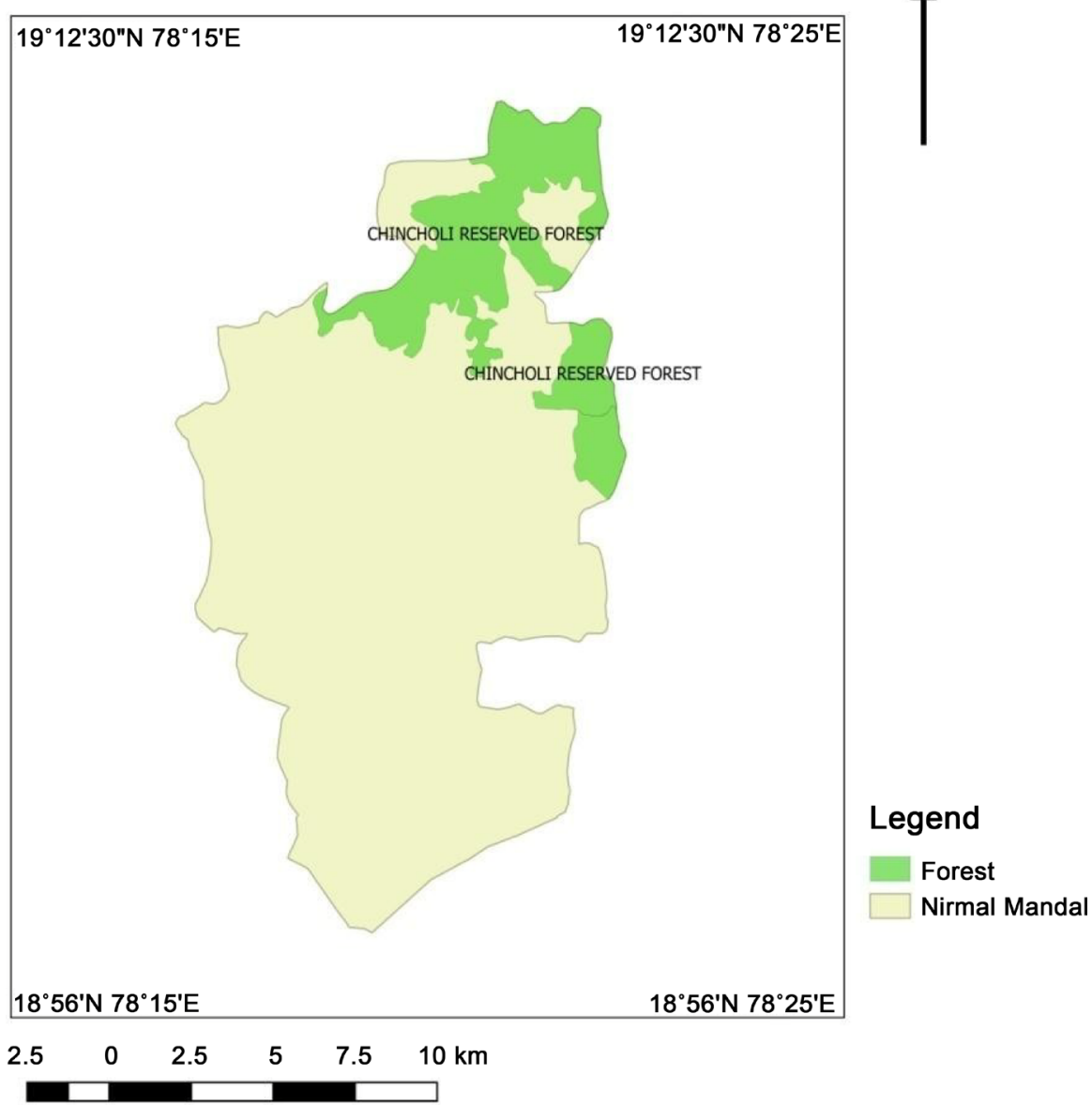

Figure 6. Thematic map of Forest land in Nirmal Mandal, Adilabad, Telangana, India.

bodies are rivers, streams, lakes and drainage networks. To protection and management of water and land resources sustainable utilization of land and water resources with least effect on the resources and environment (Plate 3(a)) [31] [32], Marine area active changes also part of water resources which will easily to determine by the remote sensing technology [33]. The data indicates that the area under water bodies has no change. A small pond has been destroyed due to urbanization which has no effect on the drainage system (Figure 7).

\subsection{Barren Land}

Bareen land contains Scrubland, sandy area, Barren Rocky Desert Coastal dry land and riverine sandy areas. Natural resources of barren land formed due to afforestation, rapid industrialization, urbanization, a rise environmental issues such as climate changes, soil erosion and flood [34] [35]. Determination of barren land information provided by the remote sensing techniques and to calculate the degradation of barren land with accurate. The data indicates that there is a significant $7.6 \%$ (Table 1). This is due to the converting of the barren land into the build-up land as a part of urbanization (Figure 8) (Plate $3(\mathrm{~b}))$. 


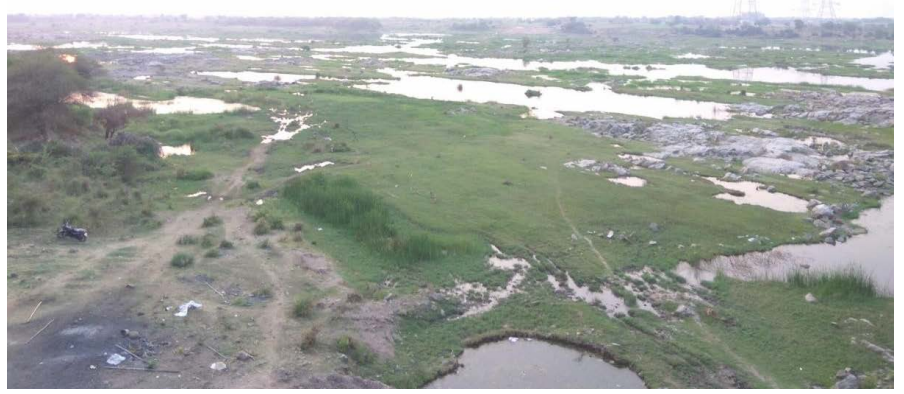

(a)

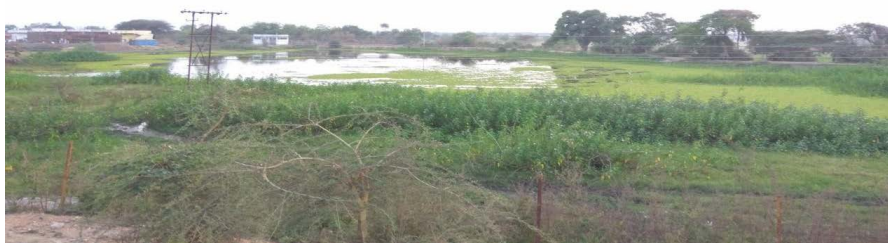

(b)

Plate 3. (a) Sriram Sagar (Godavari) Downstream, Nirmal Mandal, Adilabad district, Telangana; (b) Over View of Ganjal Village, Nirmal Mandal, Adilabad District, Telangana.

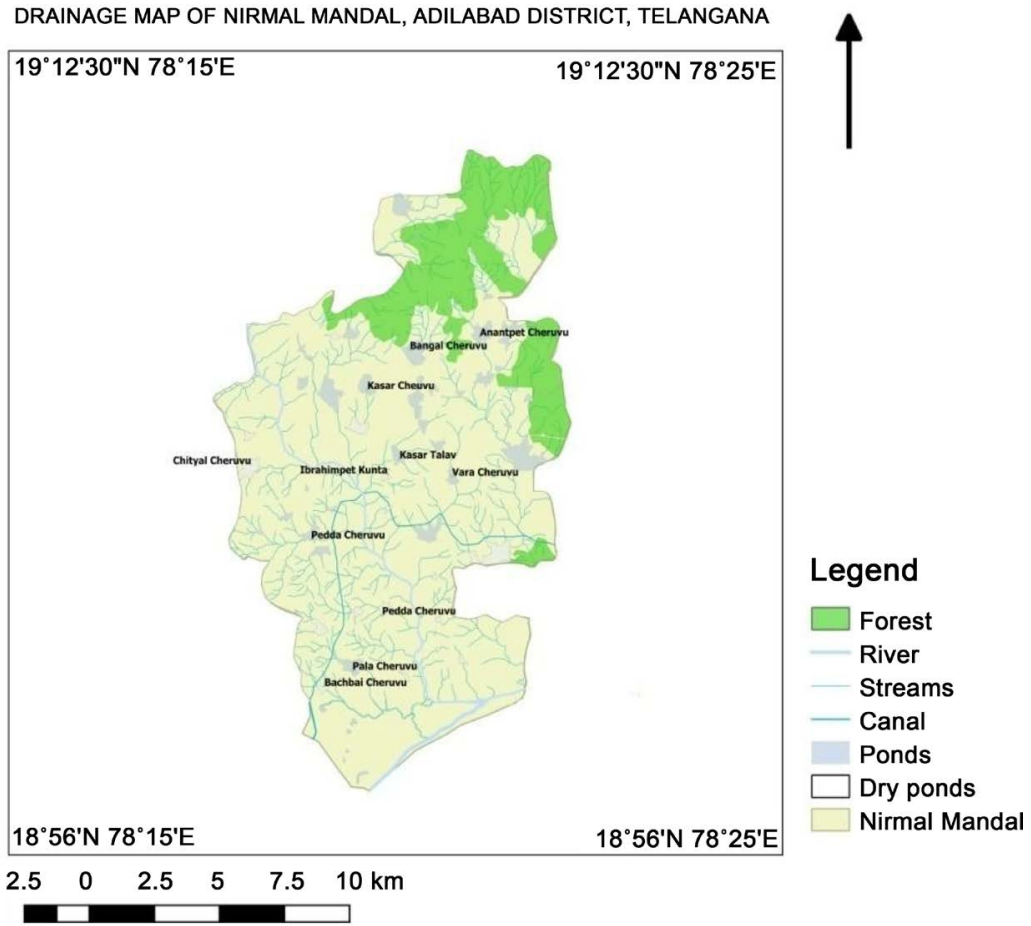

Figure 7. Drainage map of Nirmal Mandal, Adilabad, Telangana, India. 
Table 1. Area of land use classes in 2015 Nirmal Mandal, Adilabad district, Telangana, India.

\begin{tabular}{cccc}
\hline S.no. & Class name & Area in sq.km & Percentage \\
\hline 1 & Agricultural land & 99.7 & $45.70 \%$ \\
2 & Built-up land & 19.9 & $9.10 \%$ \\
3 & Forest & 17.3 & $7.90 \%$ \\
4 & Barren land & 16.5 & $7.60 \%$ \\
5 & Uncultivated land & 64.8 & $29.70 \%$ \\
& Total geographical area & 218.2 & $100 \%$ \\
\hline
\end{tabular}

BARREN LAND MAP OF NIRMAL MANDAL, ADILABAD DISTRICT, TELANGANA

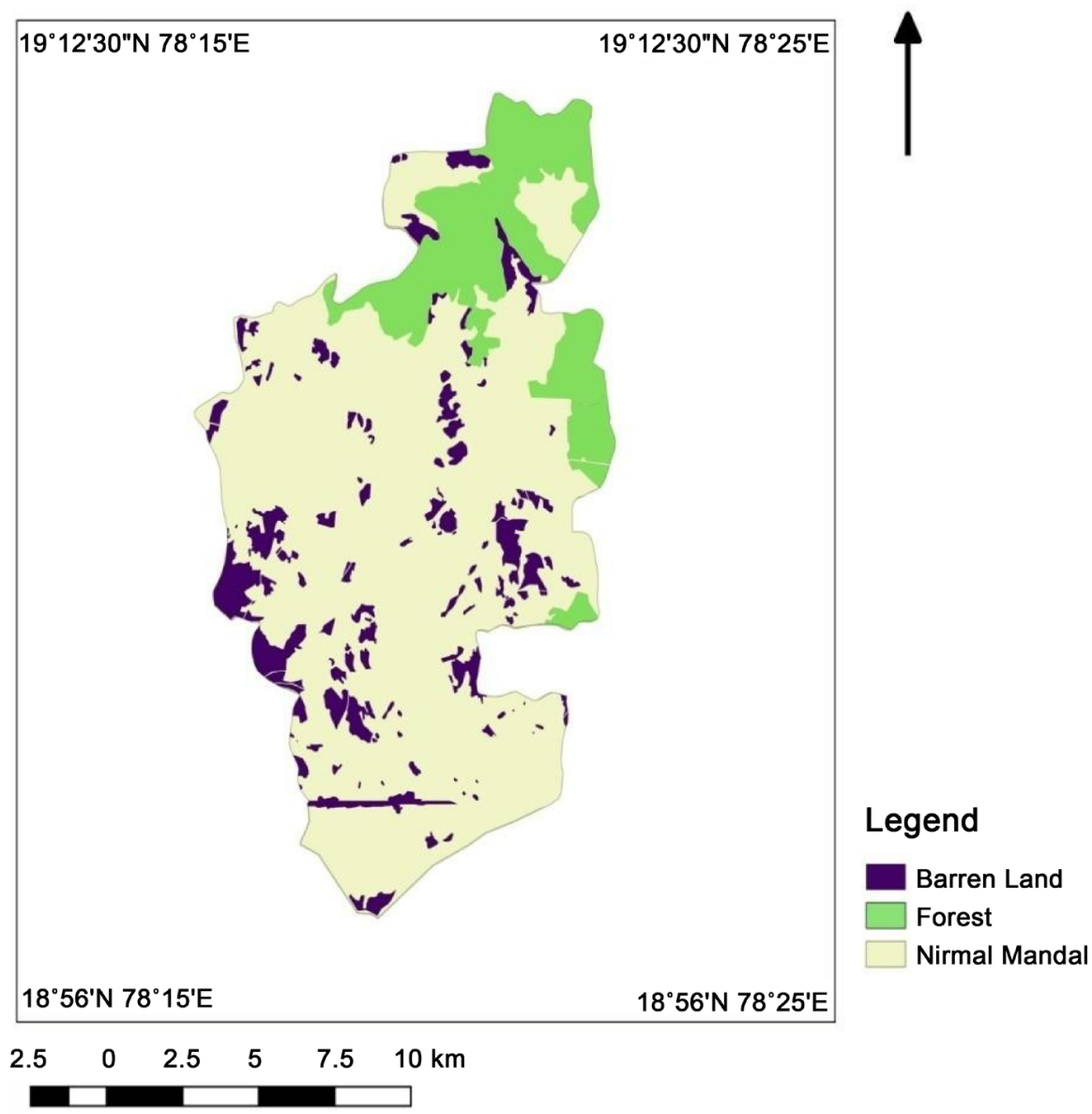

Figure 8. Barren land thematic map of Nirmal Mandal, Adilabad, Telangana, India.

\section{Conclusions}

Mapping and monitoring of land use/land cover is important for many management and planning activities as it is considered as an important element for understanding the earth and its whole system. The present study shows how well LU/LC classification carried out using Remote Sensing and GIS technology. The results show that there is noticeable built-up and agriculture about 3.3\% and 9\% respectively. There is no significant fluctuation in the case of water bodies and 


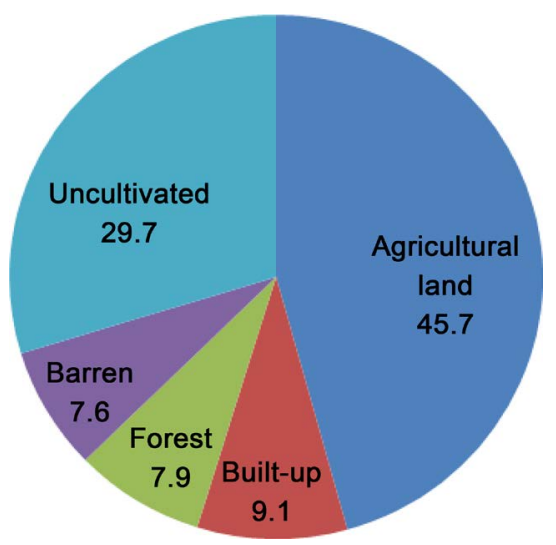

Figure 9. Graphical represent of LU/LC in percentage wise, Nirmal Mandal.

forest. The classification results are likely to be affected by various factors such as the quality of the input datasets, classification methods, algorithm, etc. Information on land use/land cover and possibilities for their optimal use is essential for the selection, planning and implementation of land use schemes to meet the increasing demands for basic human needs and welfare. The attribute data of land use/land cover from the study area that data indicates that the area under agriculture has been good from $46 \%$. Built-up has $9.1 \%$. The data indicates that the area under forest land has $7.9 \%$. Forest land is protected well and there is no effect of urbanization on the forest land (Figure 9).

We concluded that 10 years once there is a heavy rainfall and also for every 3 years interval there is same amount rainfall for the consecutive years, by this we can predict the rainfall of the future years. Land use and land cover data or maps provide quality information on the present geographical condition of the area. The Nirmal mandal contains good agriculture and Forest land. Based on present LU/LC thematic data, it will be helpful to understand change detection and their impact. While growing population there are many changes occur on the land so analysis of land use and land cover is very important. Allotment of land for transportation is a big problem, but with the help of land use and land cover we can rectify the problem.

\section{References}

[1] Johnson, A., Truax, D.D., O’Hara, C.G. and Cartwright, J. (2000) Remote Sensing, GIS and Land Use and Land Cover Mapping along the 1-10 Corridor. Engineering Research Center, Mississippi State, MS. http://www.isprs.org/proceedings/XXXIV/part1/paper/00085.pdf

[2] Singh, V. and Dubey, A. (2012) Land Use Mapping Using Remote Sensing \& GIS Techniques in Naina-Gorma Basin, Part of Rewa District, M.P., India. International Journal of Emerging Technology and Advanced Engineering, 2, 151-156.

[3] Reddy, K.Y., Murali Krishna, K.V.S.G. and Reddy, S.I. (2016) Remote Sensing and GIS Based Topograghicial Mapping For Environmental Management Study. International Journal of Applied Engineering Research, 11, 1325-1334.

[4] Zubair, A.O. (2006) Change Detection in Land Use and Land Cover Using Remote Sensing Data and GIS (A Case Study of Ilorin and Its Environs in Kwara State.) 
Master's Thesis, University of Ibadan, Ibadan.

[5] Prathap, S. and Reddy, S. (2015) On Spatio-Temporal Analysis of Pulivendula Mandal, Andhra Pradesh, India using Remote Sensing and GIS. International Journal of Research in Engineering and Applied Sciences, 5, 133-143.

[6] Sridhar, B., Srinivas, E., and Sakram, G. (2016) On Remote Sensing and GIS for Mapping and Monitoring Land Use/Land Cover in and around Hazira Coastal Area, Gujarat, India. International Journal of Applied Research, 2, 220-222.

[7] Tata Babu, Ch., Padma, G.V. and Prof. Suneetha, P. (2014) Geoinformatics for Spatio-Temporal Analysis of Land Use Dynamics in Bobbili Mandal, Vizianagaram District, Andhra Pradesh. International Journal of Engineering Sciences \& Research Technology, 3, 401-408.

[8] Thenkabail, P.S., Gangadhara Rao, P., Biggs, T.W., Krishna, M. and Turral, H. (2007) The Spectral Matching Techniques to Determine Historical Land-Use/Land-Cover (LULC) and Irrigated Areas Using Time-Series 0.1-Degree AVHRR Pathfinder Datasets. American Society for Photogrammetry and Remote Sensing, 23, 1029-1040.

[9] Babykalpana, Y. and Dr. ThanushKodi, K. (2010) On Supervised/Unsupervised Classification of LULC Using Remotely Sensed Data for Coimbatore City, India. International Journal of Computer Applications, 2, 26-30.

https://doi.org/10.5120/679-956

[10] Areendran, G., Prakash, R., Krishna, R., Sraboni, M. and Kanchan, P. (2012) Land Use/Land Cover Change Dynamics Analysis in Mining Areas of Singrauli District in Madhya Pradesh, India. International Society for Tropical Ecology, 54, 239-250.

[11] Ashraf, D.M. and Yasushi, Y. (2009) Using Remote Sensing and GIS to Detect and Monitor Land Use and Land Cover Change in Dhaka Metropolitan of Bangladesh during 1960-2005. Environmental Monitoring and Assessment, 150, 237-249.

[12] Andrew, W.D., Anette, R. and Christian, T. (2003) Historical Footprints in Contemporary Landuse Systems: Forest Cover Changes in Savannah Woodlands in the Sudano-Sahelian Zone. Global Environmental Change, 13, 235-254.

[13] Amol, V.D. and Bharti, G.W. (2013) Analysis and Modeling of Agricultural Land Use using Remote Sensing and Geographic Information System. International Journal of Engineering Research and Applications, 3, 81-91.

[14] Anil, N.C., Jai Sankar, G., Jagannadha, R.M., Prasad, I.V.R.K.V. and Sailaja, U. (2011) Land Use/Land Cover and Change Detection from Parts of South West Godavari District. The Journal of Indian Geophysical Union, 15, 187-194.

[15] Appala, R.N., Harikrishna, K., Suneetha, P. and Sachi, S.D. (2013) Land Use/Land Cover Analysis through Remote Sensing and GIS Techniques: A Case Study of Vizianagaram District, Andhra Pradesh, India. International Journal of Emerging Technology and Advanced Engineering, 3, 274-281.

[16] Sarma, V.V.L.N., Murali Krishna, G., Hema Malini, B. and Nageswara, R.K. (2001) Landuse/Landcover Change Detection through Remote Sensing and Its Climatic Implications in the Godavari Delta Region, Indian Society of Remote Sensing. Journal of the Indian Society of Remote Sensing, 29, No. 1\&2.

[17] Selvam, S. (2012) Use of Remote Sensing and GIS Techniques for Land Use and Land Cover Mapping of Tuticorin Coast, Tamilnadu. Universal Journal of Environmental Research and Technology, 2, 233-241.

[18] Petit, C., Scudder, T. and Lambin, E. (2000) Quantifying Processes of Land-Cover Change by Remote Sensing: Resettlement and Rapid Land-Cover Changes in South-Eastern Zambia. International Journal of Remote Sensing, 22, 3435-3456. 
[19] Mallupattu, P.K., Reddy, J. and Sreenivasula, R. (2013) Analysis of Land Use/Land Cover Changes using Remote Sensing Data and GIS at an Urban Area, Tirupati, India. The Scientific World Journal, 2013, Article ID: 268623.

[20] Padma Kumari, K. and Srinivas, K. (2015) Change Detection Matrix Analysis of Landuse/Landcover Mapping of 11 Mandals using Remote Sensing and Geograpical Information Systems in Costal Part of East Godavari District, Andhra Pradesh, India. University of Delhi, 266-274.

[21] Pandian, Rajagopal, Sakthivel and Amrutha, D. (2014) Land Use and Land Cover Change Detection using Remote Sensing and GIS in Parts of Coimbatore and Tiruppur Districts, Tamil Nadu, India. International Journal of Remote Sensing \& Geoscience, 3, 15-20.

[22] Ghosh, S., Sen, K.K., Rana, U., Rao, K.S. and Saxena, K.G. (1996) Application of GIS for Land-Use/Land-Cover Change Analysis in a Mountainous Terrain. Journal of the Indian Society of Remote Sensing, 24, No. 3.

[23] Karanam, H., Nadipena, A.R., Velaga, V.R., Gummapu, J. and Edara, A. (2013) Land Use/Land Cover Patters in an around Kolleru Lake, Andhra Pradesh, India using Remote Sensing and GIS Techniques. International Journal of Remote Sensing \& Geoscience, 2, 1-7.

[24] Faleh Mahmood, H. and Ali, A.N. (2013) Using Remote Sensing Techniques to Assess Land Use/Land Cover Change in Laylan Sub-District, Kirkuk Province, Iraq. Iraqi Journal of Science, 55, 845-851.

[25] Al-Razzaq Abd, H.A. and Alnajjar, H.A. (2013) Maximum Likelihood for Land-Use/Land-Cover Mapping and Change Detection using Landsat Satellite Images: A Case Study "South of Johor”. International Journal of Computational Engineering Research, 3, 26-33.

[26] Keshava Kiran Kumar, P.L., Raghu Babu, K. and Siva Kumar Reddy, P. (2017) Mapping of Landuse Landcover using Remote Sensing and GIS Techniques; A Case Study in Pullampeta Mandal, Y.S.R District, Andhra Pradesh, India. Imperial Journal of Interdisciplinary Research, 3, 2429-2433.

[27] Khadri, S. and Moharir, K. (2016) Land Use/Cover Disturbance Due to Increase in Urbanization Man River Basin of Akola Buldhana Districts, Maharashtra India. International Journal of Advanced Computer Technology, 5.

[28] Kumar Joshi, P.K., Roy, P.S., Singh, S., Agrawal, S. and Yadav, D. (2006) Vegetation Cover Mapping in India using Multi-Temporal IRS Wide Field Sensor (WiFS) Data. Remote Sensing of Environment, 103, 190-202.

[29] Manonmani, R. and Mary, D.S.G. (2010) Remote Sensing and GIS Application in Change Detection Study in Urban Zone using Multi Temporal Satellite. International Journal of Geomatics and Geosciences, 1, 60-65.

[30] Minakshi, R., Chaurasia, P. and Sharma, K. (1999) Landuse/Land Cover Mapping and Change Detection using Satellite Data-A Case Study of Dehlon Block, District Ludhiana, Punjab. Indian Society Remote Sensing, 27, 115.

[31] Nagarajan, N. and Poongothai, S. (2011) Identification of Land Use and Land Cover Changes using Remote Sensing and GIS. International Journal of Engineering and Technology, 3, 570-576.

[32] Naresh Kumar, D., Nune Sandeep, S. and Jyothi, T.M. (2017) Significant Changes on Land Use/Land Cover by using Remote Sensing and GIS Analysis-Review. International Journal of Engineering Science and Computing, 7, 5433-5435.

[33] Rahman, A., Kumar, S., Fazal, S. and Siddiqui, M.A. (2011) Assessment of Land Use/Land Cover Change in the North-West District of Delhi using Remote Sensing 
and GIS Techniques. Journal of the Indian Society of Remote Sensing.

[34] Nayana Ratnaparkhi, S. and Bharti Gawali, W. (2015) Classification of Land Use and Land Cover using Remotely Sensed Data for Parbhani City, Maharashtra, India. International Journal of Science and Research, 4, 269-272.

[35] Omo-Irabor, O.O. and Oduyemi, K. (2002) A Hybrid Image Classification Approach for the Systematic Analysis of Landcover Changes in the Niger Delta Region. University of Abertay, Bell Street. 